\title{
Chapter 10 \\ Platforming for Path-Breaking? \\ The Case of Regional Electromobility \\ Initiatives in Germany
}

\author{
Jörg Sydow and Friedemann Koll
}

\section{Electromobility Ante Portas?}

Formulating platform policies, or "platforming" for short, is becoming increasingly popular in both innovation research and practice, where they are used for either inducing regional knowledge-creating processes or overcoming the closed nature of regional clusters that have, or have been, developed (Asheim, Boschma, \& Cooke, 2011; Cooke, 2011). Platforming is the process of arriving at "regional resource configurations based on the past development trajectories but presenting the future potential to produce competitive advantage existing in the defined resource configurations" (Harmaakorpi, 2006, p. 1089). It focuses on injecting diversity or, more precisely, what is commonly called "related variety" (Boschma \& Frenken, 2011b; Frenken, van Oort, \& Verburg, 2007), into regional developmental processes in terms of knowledge resources, agents, activities, and relations. To this end, platforming sets out from the already existing knowledge base of a particular region but is commonly understood as a strategy that is more combinative than cumulative, as one designed to foster cross-sectorial coordination and learning aimed at cross-fertilization. But can such platforming be used to break away from an established regional knowledge path? That is, can it be used to reconstitute choice for the actors who follow the current path but succeed in deviating from it in some significant way? This definition of path-breaking builds on the increasing convergence in theorizing path dependence, at least in organization science and regional studies.

\footnotetext{
J. Sydow $(\square)$

School of Business \& Economics, Freie Universität Berlin,

Boltzmannstr 20, 14195 Berlin, Germany

e-mail: joerg.sydow@fu-berlin.de

F. Koll

School of Business \& Economics, Path Dependene Research Center,

Freie Universität Berlin, Garystr 21, 14195 Berlin, Germany

e-mail: friedemann.koll@yahoo.com
} 
The electromobility initiative in Germany, launched in response to global warming caused by high carbon emissions, and boosted in the aftermath of the global financial crisis that erupted in 2008, provides a suitable case for investigating the potential of platforming to unlock path dependencies that are likely to be more than technological in nature. Battery electric vehicles (BEVs) might be on the way to becoming the most serious challenger to the traditional fossil-fuel powertrain technology driven by internal combustion engines. Even though significant technological progress is a crucial factor, it is not enough in the development of the electric car (Kirsch, 2000). Battery-charging infrastructure has to be built, new organizations created and existing ones adapted, intelligent traffic concepts developed, and new business models designed to pave the way for this technological alternative. All these technological and socioeconomic challenges are addressed in the corresponding policy initiative, the National Platform for Electromobility (NPE) set up by the federal German government in 2010. Involving all the relevant national actors, yet adopting a clear regional focus, it offers a framework for discerning the extent to which platforming can change an entrenched technological path at a regional level, that is, tightly intertwined with institutional and organizational path dependencies. At the very least, platform policies such as the NPE may be capable of opening new opportunities.

We ask under what conditions platforming may be a suitable, if only a complementary, strategy for regional path-breaking change. To answer this question, we first review the present state of theorizing on path dependence and path-breaking and locate the role of platform policies systematically within this effort, paying particular heed to regional knowledge-creation processes. We then summarize the emergence and development of the electromobility initiative in Germany, which has a strong regional focus, during the four and a half years from summer 2007 through early 2012. After describing our research setting, we explain our research design and methods. That section is followed by a presentation of our empirical insights from two metropolitan regions that differ significantly in their current knowledge resources and their dependence on the automotive industry: the region of Germany's capital city, Berlin, which has little industrial production; and of Stuttgart, a core hub of Germany's automobile production. We begin with the idea that platform policies may, under certain circumstances, contribute to breaking a technological, institutional, and/or organizational knowledge path, or may at least open new opportunities. Our empirical insights lead us to the tentative conclusion that platforming may contribute to path-forming but not necessarily to path-breaking at a regional level.

Our study contributes to the rising discourse on the possibilities and limitations of platforming as a potential "post-cluster" (Cooke, 2011, p. 307) regional policy approach with a particular focus on breaking or forming technological, institutional, and/or organizational paths in regions. With regard to the continuing emphasis on regional knowledge creation and exploitation, our inquiry contributes broadly to the knowledge-based theorizing of regional economic development and, thereby, also to popular evolutionary and institutional theorizing about regional development processes. 


\section{The Theory of Path Dependence and Path-Breaking and the Role of Platforming}

For decades regional clusters (e.g., Bathelt, 2005; Lazzeretti, Sedita, \& Caloffi, 2014; Martin \& Sunley, 2003; Porter, 2000) have been seen as hot spots of knowledge creation and transfer or, more broadly, learning (e.g., Bathelt, Malmberg, \& Maskell, 2004; Cooke, 2001; Ibert, 2007; Malmberg \& Maskell, 2002; Maskell, 2001; Morgan, 1997). This view cumulated over the years into the conception of clusters as the institution for knowledge-based economic development, although negative path dependencies and even the dangers of lock-ins have also been recorded with respect to clusters for some time (Grabher, 1993; Hassink, 2005, 2010; Henning, Stam, \& Wenting, 2013; Lagerholm \& Malmberg, 2009; Martin, 2010; Martin \& Sunley, 2006). The path dependence of knowledge development has been noted for regions and geographical network trajectories (Glückler, 2007) as well as for firms and other types of organizations and their knowledge management practices (Coombs \& Hull, 1998; Nooteboom, 1997). In regional clusters this phenomenon is, hence, likely to have its roots not only in technological but also institutional and organizational path dependencies (Sydow, Lerch, \& Staber, 2010).

Path dependence is mostly used with the broad meaning of "history matters," less often in a much more specific, analytical sense alluding to the seminal works of Paul David (1985) and W. Brian Arthur (1994). In this chapter we adopt this latter understanding, which is currently also conquering the analysis of regional development processes and might eventually be used for additional cumulative knowledge production on cluster formation and transformation processes in economic geography (Bathelt \& Boggs, 2003; Boschma \& Fornahl, 2011; Henning et al., 2013; Li, Bathelt \& Wang, 2012; Tödtling \& Trippl, 2013; Wolfe \& Gertler, 2006). What is more, we try to clarify the relationships between this particular understanding of path dependence and the challenging task of path-breaking-and the role that platforming may have therein. Such clarification is necessary if actors wish to have strategic influence on the development of a regional cluster.

According to David (1985), who developed this understanding based on his research on QWERTY, ${ }^{1}$ path dependence is understood as a tapering process triggered by a small event and leading, at least potentially, into a lock-in. For three reasons, this understanding is more specific than the general argument that history matters. First, a small event (which in the case of QWERTY is still debated; see Kay, 2013) triggers the tapering process of becoming more dependent on the course of action embarked on after this event. Second, from a certain point in time often retrospectively called a "critical juncture" (Collier \& Collier, 1991), positive feedback mechanisms take over and make it increasingly difficult to leave the given course of action, or path. These mechanisms make the once-chosen path increasingly attractive. Economists typically refer to this phenomenon as "increasing

\footnotetext{
${ }^{1}$ QWERTY refers to the most common keyboard layout for Latin script. The name derives from the sequence of the first six keys in the upper left row of letters when read from left to right.
} 
returns" (Arthur, 1994), although they have also become more receptive to explanations other than decreasing unit costs or network effects (David, 2001). Third, this path-dependent process is likely to lead to a lock-in, that is, a situation in which actors are stuck with former choices because an alternative course of action is no longer feasible.

Building on the works of David and Arthur as well as on that in political science (e.g., Mahoney, 2000; Pierson, 2000; Thelen, 1999), the ascendant theory of organizational path dependence (Sydow, Schreyögg, \& Koch, 2009) highlights the importance of imprinting processes, the notion that history already matters in the preformation phase of a path. In keeping with earlier contributions and with much thinking in economic geography (see Henning et al., 2013), this theory also underlines the importance of self-reinforcing processes triggered by one or more events or actions that narrow down alternatives in the formation phase, including coordination, complementarity, and particular kinds of learning effects. Finally, like the original conception by David and Arthur, the theory of organizational path dependence stresses the lack of any realistic alternatives in the lock-in phase. Nevertheless, it asserts the importance of considering agency also in this last phase because agents do not simply have to take the path; they are capable of making on-path changes and, under specific circumstances, of shaping, leaving, or even breaking the existing path.

Although this theory is fairly new, it has already been applied explicitly to the analysis of a nascent cluster (optics), for which the relevance of technological, institutional, and organizational factors for regional path dependence was pointed out by Sydow et al. (2010). More significant, however, the theory of organizational path dependence is consistent with recent developments in the theory of regional path dependence (in the fields of economic geography and regional studies, see especially Henning et al., 2013; Martin \& Sunley, 2006). Table 10.1 gives an overview of the most important features of this theorizing in four important streams of literature.

Path-breaking activities, which do not necessarily imply the creation of a new path, can be different in nature and degree, but there is a minimum requirement:

Since the process of becoming path dependent has been framed as progressively eliminating the scope of decision making, this minimum condition is the effective restoration of a choice situation - the insertion of at least one alternative course of action. However, opening the window for an alternative is necessary but not sufficient. The new alternative has to be a superior one (Arthur, 1994), because implanting an inferior one would not constitute a real choice. (Sydow et al., 2009, p. 702)

Of course, what is perceived as a real choice by the actors or outside observers depends heavily on context. In reality, it is less a question of choice or no choice than of degree. A more realistic understanding of path-breaking would therefore be geared to increasing the scope of choice.

A potential means of path-breaking in this sense is platforming, which tries to (re)introduce diversity, related variety in particular, into a developmental process, including a regional knowledge path. In the case of forming a new path, a certain amount and composition of such related variety is required. However, both are hard 
Table 10.1 The theory of path dependence in different disciplines and fields of study

\begin{tabular}{|c|c|c|c|c|}
\hline $\begin{array}{l}\text { Important } \\
\text { features }\end{array}$ & Economics $^{\mathrm{a}}$ & Political science $^{a}$ & $\begin{array}{l}\text { Organization } \\
\text { science }^{\mathrm{b}}\end{array}$ & Regional studies $^{\mathrm{b}}$ \\
\hline $\begin{array}{l}\text { Primary } \\
\text { object of } \\
\text { study }\end{array}$ & Technologies & Institutions & Organizations & $\begin{array}{l}\text { Regions, in } \\
\text { particular regional } \\
\text { clusters comprising } \\
\text { all three }\end{array}$ \\
\hline $\begin{array}{l}\text { Triggering } \\
\text { event }\end{array}$ & Small & Small or big & Event or action & Event or action \\
\hline Role history & $\begin{array}{l}\text { Matters only } \\
\text { after the event }\end{array}$ & Unclear & $\begin{array}{l}\text { Historical imprints } \\
\text { also matter before } \\
\text { the event/action }\end{array}$ & $\begin{array}{l}\text { Historical imprints } \\
\text { also matter before } \\
\text { the event/action }\end{array}$ \\
\hline $\begin{array}{l}\text { Self- } \\
\text { reinforcing } \\
\text { mechanisms }\end{array}$ & $\begin{array}{l}\text { Increasing } \\
\text { returns at the } \\
\text { center }\end{array}$ & $\begin{array}{l}\text { Learning more } \\
\text { generally, } \\
\text { complementarity } \\
\text { and coordination } \\
\text { effects }\end{array}$ & $\begin{array}{l}\text { Coordination and } \\
\text { complementarity } \\
\text { effects, single- } \\
\text { loop learning, } \\
\text { adaptive } \\
\text { expectations }\end{array}$ & $\begin{array}{l}\text { Coordination and } \\
\text { complementarity } \\
\text { effects, learning, } \\
\text { adaptive } \\
\text { expectations }\end{array}$ \\
\hline Agency & $\begin{array}{l}\text { Agency } \\
\text { restricted to } \\
\text { reproducing } \\
\text { the path }\end{array}$ & $\begin{array}{l}\text { Political interests } \\
\text { and power, agency } \\
\text { also shaping the } \\
\text { path }\end{array}$ & $\begin{array}{l}\text { Interests and } \\
\text { power, agency in } \\
\text { all phases of the } \\
\text { process }\end{array}$ & $\begin{array}{l}\text { Interests and power, } \\
\text { agency in all phases } \\
\text { of the process }\end{array}$ \\
\hline Contributors & $\begin{array}{l}\text { David (1985, } \\
\text { 2001), Arthur } \\
\text { (1994), and } \\
\text { many others } \\
\text { with mainly an } \\
\text { application } \\
\text { focus on } \\
\text { technological } \\
\text { developments; } \\
\text { North (1990) } \\
\text { famously } \\
\text { pointing to } \\
\text { economic } \\
\text { institutions }\end{array}$ & $\begin{array}{l}\text { Thelen (1999); } \\
\text { Pierson (2000); } \\
\text { and Mahoney } \\
(2000)\end{array}$ & $\begin{array}{l}\text { Sydow, } \\
\text { Schreyögg, \& } \\
\text { Koch (2009); } \\
\text { Sydow, Lerch, \& } \\
\text { Stabe (2010); } \\
\text { Schreyögg, } \\
\text { Sydow, \& } \\
\text { Holtmann (2011); } \\
\text { Manning \& } \\
\text { Sydow (2011) }\end{array}$ & $\begin{array}{l}\text { Grabher (1993); } \\
\text { Bathelt \& Boggs } \\
\text { (2003); Hassink } \\
\text { (2005, 2010); } \\
\text { Martin \& Sunley } \\
\text { (2006); Glückler } \\
\text { (2007); Lagerholm } \\
\text { \& Malmberg } \\
\text { (2009); Martin } \\
\text { (2010); Henning, } \\
\text { Stam, \& Wenting } \\
\text { (2013) }\end{array}$ \\
\hline
\end{tabular}

aiscipline

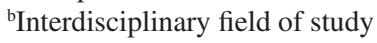

to establish ex ante. Breaking an existing path or opening it to additional choices, may call for additional related variety. Admittedly, related variety constitutes an underdetermined and insufficient, but necessary, condition for any concept of pathforming or path-breaking.

Although the idea of platforming has arisen only recently (see also Asheim et al., 2011; Cooke, 2007, 2012; Harmaakorpi, 2006; Harmaakorpi, Tura, \& Melkas, 2011), examples are found in a handbook (Cooke \& De Laurentis, 2010, pp. 294 309), at the interface of art and food in an Italian region (Lazzeretti, Capone, \& Cinti, 2010), in emerging innovation policies of several Finnish regions (Uotila, Harmaakorpi, \& Hermans, 2012), and in urban regions of Canada (Wolfe, 2013). 
Drawing on the insights these sources provide and anticipating the findings of our own empirical study, we see platforming as building on and steering regional resource configurations and as developing common cognitive-normative frames that foster collaboration, not least between private and public sector organizations, yet also as preventing the collaboration from drifting toward premature rigidity.

The concept of platforming, whether or not appropriately labeled as a postcluster policy approach, is explicitly related by its protagonists not only to cluster policies per se but to regional path dependencies and this type of rigidity in particular (e.g., Cooke, 2011, p. 307). The core concept of platforming, with its powerful idea of related variety borrowed from evolutionary economics, aims directly at counterbalancing the market-driven focus that conventional cluster policies, often with reference to Porter (2000), have on rather closed industries and industry-related settings and their emphasis on the homogeneity of knowledge configurations.

Against this background it comes as no surprise that the spectrum of regional platform actors, activities, resources, and relations is broader than that of clusters and is even less well captured by the industry concept still dominating cluster research and policy. Instead of narrowing the scope of actors and activities, platforming aims at widening it. At least as important, the concept stresses the understanding of regional trajectories and a conscious avoidance of negative path dependence and regional lock-in by promoting the identification and construction of competitive configurations of assets and by providing access to rather diverse knowledge resources through relationship-building and cross-fertilization. Because related variety is a necessary, but not sufficient, condition for path-forming or -breaking, what is needed in addition are events that help focus attention on new circumstances and the urgent need for eventual change in a regional field or cluster. In this respect the concept of field-configuring events (FCE), currently on the rise in organization studies (e.g., Schüßler, Rüling, \& Wittneben, 2014), is useful and can be related to platforming.

Referring to work by Meyer, Gaba, and Colwell (2005) on the role of conferences for structuring organizational fields, Lampel and Meyer (2008) define FCEs more broadly as

temporary social organizations such as tradeshows, professional gatherings, technology contests, and business ceremonies that encapsulate and shape the development of professions, technologies, markets, and industries (Meyer et al., 2005). They are settings in which people from diverse organizations and with diverse purposes assemble periodically, or on a one-time basis, to announce new products, develop industry standards, construct social networks, recognize accomplishments, share and interpret information, and transact business. FCEs can enhance, reorient, or even undermine existing technologies, industries, or markets; or alternately, they can become crucibles from which new technologies, industries, and markets emerge. Recognizing this, their organizers often design FCEs with an eye towards influencing field evolution. (p. 1026)

FCEs are thus an important concept for understanding and a means of executing platform policies, no matter whether they are of a rather continuous or disruptive nature. Despite, or because of, the relatedness of the FCE concept to "temporary clusters" (Maskell, Bathelt, \& Malmberg, 2006), it has not yet been fully exploited by economic geographers in the context of understanding and influencing regional development. 
Regardless of how important FCEs are considered to be for platforming, structures beyond the particular event are needed. These structures allow agents to refer to them as they strive to influence the development of a regional knowledge base, be it at the field, cluster/network, or organizational level (Giddens, 1984). By referring to these rules and resources in practice, agents reproduce or transform these structures, helping others make sense of related variety to establish common ground for their potentially diverse interests. This solid foundation can, in turn, facilitate future collaboration and coordinated action with a comparatively long-term perspective in order to build momentum in and beyond the FCEs.

\section{Studying Electromobility Initiatives in the Metropolitan Regions of Berlin and Stuttgart}

Industrial and political actors recently discovered, or rather rediscovered, electromobility as a promising future technology for urban mobility. In a narrow sense, on which we focus in this chapter, this term coined politically by the German federal government refers only to BEVs, range-extended electric vehicles (REEVs), and plug-in hybrids (PHEVs). It is believed that these three constituent technologies will spread at least in urban areas and thereby contribute to the reduction of carbon dioxide once an adequate regional battery-charging infrastructure is provided (German Federal Government, 2009, pp. 5-7).

We begin by explaining our research design and methods and presenting our empirical insights into policy-making at both the federal and state levels in Germany. Focusing for obvious reasons exclusively on the early stages of these processes, we point out the importance of agenda-setting at the federal level before the implementation of the NPE. Then we look into how the creation of the NPE triggered a process of path-formation at both levels. The chapter concludes with an investigation mainly of the NPE's regional effects. Although the German NPE is primarily the outcome of federal policies, it has had a strong regional focus from the outset. This aspect is important in face of the regional battery-charging infrastructure necessary for electromobility. Even more important, as we show, is the fact that the NPE provided significant economic incentives for industries and regional politicians to join the platforming initiative. Whereas the involved industries mainly sought to decrease their technological uncertainty before engaging in serious research and development $(R \& D)$, the politicians welcomed the central government's offer of subsidies for platforming initiatives, including regional ones, to promote regional economic development in the emerging field of electromobility. 


\section{Research Design and Methods}

To capture the developments at the federal and state levels of analysis, we adopted an embedded case study design (Yin, 2009) centered on two regions-Stuttgart and Berlin-that were (and still are) embedded in the broader, very dynamic national context of electromobility in Germany. Taking Pettigrew's (1990) advice to "go for polar types" (p. 275), we chose the most dissimilar regional cases in order to ensure adequate variance across the existing regional knowledge bases and the present dependence on the automotive industry. The Stuttgart region is Germany's leading automotive cluster, with its extraordinary competence in the traditional engineering of parts and components of the internal combustion engine. Original equipment manufacturers as well as several leading first- and second-tier suppliers have their headquarters there. It is also a region already analyzed for path dependence and possible lock-in (Fuchs, 2010; Fuchs \& Wassermann, 2005; Kaiser, 2007; Strambach \& Klement, 2013). At the other extreme, we opted for the capital region of Berlin, which is characterized by a substandard number of industrial jobs, particularly in the automotive sector. However, Berlin is widely seen as a hot spot for the creative industries (Lange, Kalandides, Stöber, \& Mieg, 2008), including alternative means of transportation and mobility. At the onset of the developments in the field of electromobility, the socioeconomic conditions of these two metropolitan regions differed significantly. ${ }^{2}$ The study covered a period of more than 4 years starting in summer 2007, when the political agenda-setting gained momentum, and ending in early 2012, when both regions were selected as electromobility showcases, a federal program that funds large-scale regional demonstration projects to consolidate innovative elements of electromobility and make them visible internationally. These projects may be considered as an advance indication that the contours of the new field were becoming fairly clear.

Unexceptionally for case study research, our inquiry draws on multiple sources of evidence (Eisenhardt, 1989). The main sources of data are 27 semistructured interviews conducted by the second author with representatives of relevant groups of actors at the national level (3 interviews) and regional level (16 in the Berlin region, 8 in the Stuttgart region) in mid-2011. At the national level representatives of participating federal authorities were interviewed. At the regional level the interviewees were experts from regional companies, regional institutions, local administrations, and research organizations. The average interview length was $67 \mathrm{~min}$. Twenty interviews were conducted face to face on-site; seven interviews had to take place by telephone. A semistructured guideline was used throughout all interviews to achieve a degree of uniformity concerning the subject matter discussed. Nonetheless, all interviewees were given ample space to express their own experiences and assessments. To elicit personal accounts and chronological narratives, for

\footnotetext{
${ }^{2}$ For instance, two major players in the German automotive industry, Bosch and Daimler, together employ more than 100,000 people in the Stuttgart region, a number exceeding that of all industrial workplaces in the Berlin region.
} 
example, all interviews began with an open invitation such as, "Just start telling me how you personally initially encountered the issue of electromobility." Subsequently, discussion turned to more specific topics in six thematic blocks: (a) the region's socioeconomic conditions when the field of electromobility was still nascent, (b) the general developments in that field, (c) the way(s) in which the interviewee's organization executed and planned activities, (d) the observable actor constellations and hidden interests in the region, (e) an assessment of the attempts at regional coordination between organizations and sectors, and (f) a short reflection and outlook. For the purpose of this publication, relevant quotations have been translated verbatim by the authors.

A second data source for this study is a collection of more than 150 official and internal documents published between summer 2007 and early 2012. It encompasses about 3000 pages of reports, press releases, presentations, and other material stemming from industry and government. This compilation was used predominantly to construct, or reconstruct, the hard facts of the processual developments. A third source of data is the nonparticipant observations made by the second author while at 28 events such as expert meetings, conferences, and project presentations over a 2-year period until fall 2011, attendance that resulted in more than 250 pages of personal notes. This written record covered information he gathered verbally and visually throughout the official program of each event. It included not only notes from presentations and round-table discussions but also personal impressions. Although we are far from claiming that this source even approximates a coherent ethnography, we used them to guarantee a rather nuanced assessment of the "soft facts" about the processual developments in the regional and national context.

To analyze the data, we had all the interview material (more than $30.5 \mathrm{~h}$ ) fully transcribed and encoded with a QDA software in a thematic and temporal way. We then added the data derived from the official and internal documents and from the personal notes, attached them to the thematic and temporal codings, and further elaborated on them (more than 2250 codes in all). The combination of these three data sources offered multiple perspectives on certain events, processes, relations, interests, and the like. In this phase of data analysis, we created both a national and a regional timeline of the events and processes. Applying a temporal bracketing strategy (Langley, 1999), we decomposed three distinct periods to sequence the processes and events chronologically for analytic purposes. In accordance with the theory of organizational path dependence (Sydow et al., 2009), we call these periods the preformation phase, the critical juncture, and the formation phase. We used them to structure our process description and to support our conceptual argument with empirical evidence that — at least in the case of regional electromobility initiatives-platforming strategies were being used to open the scope for new regional path-building or path-shaping activities at a fairly early stage. Although we assumed continuity within each period and a certain degree of discontinuity at its boundaries, we omitted later phases in the process, particularly the lock-in phase, because there were no indications that the new technology or knowledge path might already have reached that stage. We focused instead on the early phase of a path by zooming in on these periods before, during, and after the critical juncture. We also focused on 
FCEs because they are at least potential "critical turning points" (Lampel \& Meyer, 2008, p. 1026), where representatives of all the relevant actor groups meet occasionally to structure, or restructure, resource combinations and to keep coordinating joint action—or, more formally, aim to institutionalize the field of electromobility. In each region we identified three events that we classified as potentially fieldconfiguring in nature. Taking these steps in data analysis, we conducted a withincase analysis in each region, focusing on a detailed description of the observable events and activities that occurred between mid-2007 and early 2012. Lastly, we compared the cases across the two regions under study to elaborate commonalities and differences between the identified platforming activities.

\section{Preformation Phase: Political Agenda-Setting}

Political actions in the field of electromobility go back to a gathering of Germany's federal cabinet in August 2007. The neologism electromobility originally appeared as one of several ways to address the challenges posed by global climate change, growing energy demand, and rising oil prices as documented in the Integrated Energy and Climate Program (German Federal Government, 2007). The assumption in this report was that battery electric vehicles in particular offer two advantages. One is an enormous potential to reduce transport-related carbon dioxide emissions and the country's dependence on oil imports. The other is an apt opportunity to increase the number of primary energy sources by using the full spectrum of renewable energies to power electric vehicles in the medium and long term. This document was the first official reference to electromobility by the German government, which addressed at the very least three different industries: automotive, energy, and information and communication technology (ICT). As one early result and imprint, German car manufacturers and electric utilities announced field experiments with battery electric cars and new infrastructures in several German regions. ${ }^{3}$

In 2008 the German federal government organized the National Strategy Conference on Electromobility to provide the impetus for further action despite the peak of the financial and economic crisis gripping the world at that time. It was the first official venue at which governmental authorities, scientists, and representatives from all the relevant industries met to discuss the country's next strides in the field of electromobility and jointly underlined the future potential of this technological alternative. The necessity of increasing national $R \& D$ efforts to maintain the competitiveness of the automotive industry, the backbone of the German economy, also came

\footnotetext{
${ }^{3}$ Even earlier imprints may have been left by the abortive field tests conducted by the German automotive industry on the island of Rügen from 1992 to 1996. Unlike the current experiments, these early ones of the 1990 s were predominantly technological in nature. No coordinating national or regional institutions integrated diverse actor constellations from industry, politics, and science, nor were demonstration projects of applied science and technology set up in multiple German regions.
} 
to the fore. Needless to say, this gathering increased regional discussion about what potential reconfigurations of established value-chain architectures could lead to.

The issue of electromobility became even more important almost as a "historical accident" (David, 1985, p. 332) when the federal government announced its second economic stimulus package to mitigate the economic downturn accompanying the global financial crisis. In early 2009 an additional $€ 500$ million for R\&D, market preparation, and demonstration were provided. Eight electromobility pilot regions, including the metropolitan regions of Berlin and Stuttgart, were selected in the first half of 2009. More than one fifth of the overall budget was earmarked for these regional initiatives.

When the first period of political agenda-setting ended in August 2009, only a few months before federal elections, the German government adopted the National Electromobility Development Plan. Besides focusing on the intensified R\&D of battery systems, this incentivized roadmap also drew considerable attention to the regional scale. Among other things, the necessity of an alternative battery-charging infrastructure had to be tested, and the viability of electric vehicles had to be demonstrated in regional projects. In this respect the document comprised a mélange of climate and economic goals pushed forward by political actors, particularly highlighting the market-oriented objective of putting one million electric vehicles on Germany's roads by 2020 (German Federal Government, 2009).

Having gained momentum at the national level, the issue of electromobility spread to the Stuttgart and Berlin regions at the end of 2008 - the first time at that level. However, new regional industries to address it did not arise out of nowhere; they branched out from already existing industries (Boschma \& Frenken, 2011a). The preexisting local economic and technological environments may thus properly be regarded as either constraining or enabling the emergence (Martin, 2010, p. 20). In short, the two regions in our embedded comparative case study fundamentally differed in the inherited conditions, knowledge bases, and competencies that informed these early activities.

In the Stuttgart region an enabling precondition was evident in efforts to increase the interorganizational coordination of existing activities within the institutionalized automotive cluster in order to face future challenges in the industry. The main thrust of these early networking activities as of 2007 was to safeguard the existing value chain of powertrain technologies based on the internal combustion engine, so the new issue of electromobility was not explicitly addressed. The first reference to this new technological alternative came 1 year later, in late 2008. Key actors from the automotive industry and the energy and ICT sectors took up the then-new subject of electromobility in their joint application to two competitive national funding programs - the prestigious Leading-Edge Cluster Competition and the Electromobility Pilot Regions_-announced as part of the German federal government's second economic stimulus package. Above all, these national programs acted as a means of anchoring the issue of electromobility in the existing structure of industry for the first time. In summer 2009 the Stuttgart region was selected as a pilot region. However, the proposal for the R\&D-focused Leading-Edge Cluster Competition failed. This outcome greatly disconcerted the region's industrial actors. 
The wide automotive supplier base in particular remained largely excluded from subsequent developments in the field of electromobility, for the original equipment manufacturers with headquarters in the region hedged when disclosing their future R\&D strategies. This collective uncertainty was reinforced by several studies highlighting the threat of a regional economic downturn as a result of potential structural changes in the region's dominant industrial sector.

By contrast, the dominance of the industrial sector is much less pronounced in the Berlin region. Electromobility was adopted at the outset as a welcome starting point in the search for future topics for regional development at the interface of the transport and energy sectors to help revitalize Berlin's industrial structure. Already evident in the region's economic policy at that time, the renewed attention to the industrial sector strengthened the initial expectations of electromobility. The matter appeared on the agenda in the Berlin region for the first time when German carmakers and utilities called for proposals for demonstration projects to conduct there in 2008. Nearly all the projects that were submitted were of an applied nature. In 2009 the Berlin region was ultimately selected as a pilot region. However, the complexity of unsolved problems related to transport and urban settings surfaced when it came to installing a public charging infrastructure, a process that lagged far behind the initial schedule. In addition, an attempt to put a regional innovation network in place to pool regional companies and research institutions in the field of electromobility failed. As the first phase of path formation ended, political actors engaged in much wishful thinking, ignoring the fact that the region was serving predominantly as a technological playground for industrial actors close to federal policy but with little potential for regional value-creating activities. As noted by an interviewee from the regional innovation agency, "Although it is nice to have projects, it would be even nicer if Berlin were not only the playing field,...if some things were sustained" (Interview B003; June 2011).

\section{Critical Juncture: Organized Calls for Increased Regional Coordination}

The rather hasty and haphazard political actions taken before and after adoption of the National Electromobility Development Plan (German Federal Government, 2009) greatly unsettled the agents involved. In autumn 2009 four federal ministries were still equally responsible for the issue of electromobility. Criticism of this complex constellation and the lack of clear governmental leadership mounted in early 2010. For instance, the Commission of Experts on Research and Innovation, whose annual report includes assessment of technological performance in Germany, criticized the lack of coordinated action between the federal government and the federal states and called for increased national R\&D efforts to develop international competiveness (Expert Commission on Research and Innovation, 2010, pp. 65-76). The National Academy of Science and Engineering (2010) challenged the government's 
incomplete focus on market-oriented goals and endorsed instead its own aspiration to make Germany both a lead market and a lead provider, which the academy believed more suitable for safeguarding the future competitiveness of German industry.

As a result, an interdepartmental Joint Unit for Electric Mobility was founded in spring 2010 to pool competencies and the federal government's activities in the field. Since then, this Joint Unit has been the government's sole contact for key stakeholders from industry and research organizations. It is headed by the Federal Ministry of Economics and Technology and the Federal Ministry of Transport, Building, and Urban Affairs. One of the main tasks of this newly created governmental institution was to organize the NPE's constitutive convention. Meanwhile, industrial actors, mainly under the aegis of the Federation of German Industry (BDI) and the German Association of the Automotive Industry (VDA), agreed on a joint approach to collaboration in the projected multistakeholder platform intended to encompass politicians, industry associations, trade unions, the automotive industry, the energy and ICT sector, research organizations, and other interested parties. Before the NPE's inaugural event, which took place in May 2010 with more than 400 invited guests attending, representatives of industry and government agreed to a joint declaration that underscored their commitment to increasing cross-sector and interorganizational coordination despite the manifestly conflicting interests of the relevant stakeholders (German Federal Government, 2010). The NPE now consists of a steering committee, seven specific technological working groups, and almost 150 members in total. The goal is to lay the foundations of a concerted and consistent R\&D strategy among key stakeholders from industry, science, and other relevant spheres of society to provide the basis for future governmental financial support. Hence, the NPE became the central place of intersectorial exchange, where major pillars of the burgeoning national innovation system were developed. This organization's creation marks a fundamental break with the previous political goal of establishing a lead market for electromobility. Instead, the industrial dimension of the initiative - the stated aim to become a lead provider-supplemented the climate-policy goals that had dominated when the developments began in the preceding period.

The two regions responded differently to these developments. Whereas a degree of collective uncertainty pervaded the Stuttgart region, hopes about the industrial policy implications grew in the Berlin region. Despite these opposing reactions, the activities that followed had striking similarities. At FCEs in both regions, a targeted appeal to policy-makers was seen as the critical juncture in the attempt to root the issue of electromobility firmly in regional development strategies. At these gatherings industrial and institutional actors clearly articulated their call to establish an interorganizational platform at the regional level and aimed to mobilize political support for such institutionalization. We now present a relatively detailed account of these critical turning points by looking at three potentially field-configuring or -reconfiguring events in both regions.

In retrospect, a cabinet hearing in fall 2009 was the Stuttgart region's first FCE to move common awareness toward BEVs. During this event it was predominantly 
representatives of the automotive industry who clearly urged the state government to create an organizational body to intensify regional coordination. To quote a participant in the hearing, "the state ministry has to wield the baton" (Flaig, 2009). Only a few days later the call succeeded, and electromobility was henceforth commonly known, in the words of the state's minister president, as "a vital issue for the automotive region" (State Ministry of Baden-Wuerttemberg, 2009). Momentum stemming from this event led to implementation of a state initiative for electromobility in Baden-Wuerttemberg. The main mission of this initiative was to establish a regional knowledge base to promote the industrialization of electromobility along the entire value chain, including the abundant R\&D and manufacturing capabilities and capacities in the region. A representative from one of the region's original equipment manufacturers reflected on the regulatory work involved at that time:

Basically, you have to create some kind of coordinating institution-of course, without telling policy-makers what it should look like....If you continue talking about it, it will bear fruit at some point in time,...[T] his was not only us; others were just as smart and raised this topic. And let's say that is how the formation of political will developed and played out.

(Interview S002; September 2011)

In the Berlin region the first FCE took place a few months later. It stemmed from a meeting of a new industrial policy network, the Steering Committee on Industrial Policy, to discuss and amplify measures of the city's reindustrialization process. In the first session of this forum, held in spring 2010, it was agreed to pursue the recent developments in the field of electromobility as a new key aspect in the region's future economic development strategy. The ensuing political wishful thinking was reinforced by a study conducted by an international consulting firm that forecast what in retrospect were very optimistic, if not unrealistic, prospects for the region as a result of the recent developments in the field of electromobility. In the wake of the appeal by representatives of industrial and institutional stakeholders, the Berlin Senate Chancellery released an initial concept paper to confirm its willingness and its commitment to strengthen the efforts in this new area. The draft of this program was circulated by a letter to federal decision-makers and members of the NPE, which was being formed at that time. The shift toward the regional economic dimension of electromobility was highlighted by a member of the steering committee: "Obviously, a region or a city that is in a process of redefining itself anyway and questioning how it can do more regarding the question of industrial policy should grab this opportunity" (Interview B012; August 2011).

During this phase both regions had a diverse set of actors from regional industry, research organizations, industry associations, innovation agencies, trade unions, and municipal authorities who pushed to create new regional institutions such as a formal coordination agency, harmonized local regulations, and stable interorganizational and intersectorial coordination practices. These institutions seem to have been a precondition for embedding the issue of electromobility permanently in future regional development strategies. As one of the first cornerstones, regional agencies were set up as platform organizers early in the next phase. This measure 
was arguably the main result of the targeted appeal relating to the FCEs in both regions.

\section{Formation Phase: Implementing Cross-Sectorial Platform-Policies}

In November 2010 the NPE published its first interim report, which centered on the activities of the seven installed working groups. The members of the NPE were pressed for time because the financial aid provided by the second economic stimulus package was scheduled to end in 2011. Each of the seven technological working groups (e.g., battery systems, electric drivetrains, infrastructures, and framework conditions) was led by an industry representative and consisted of about twenty members. Within the framework of the NPE's interim report, each working group published its own roadmap "to set out the development paths" (National Platform for Electromobility, 2010, p. 5). The work and outcome of these groups clearly indicate that the NPE had already become more than a policy and funding announcement by the government.

In May 2011, just 1 year after the platform had been created, the NPE released its second report, in which the members pushed two central claims. First, they developed the idea of technological "lighthouse projects" (National Platform for Electromobility, 2011, pp. 16-25, e.g., the battery, drivetrain technology, ICT, and infrastructure lighthouses) to foster interorganizational and intersectorial R\&D projects. In these projects R\&D activities with a "strategic character" (p. 16) were to be bundled in keeping with the proposed roadmaps drawn up by the NPE's working groups. Second, large-scale regional showcases of applied science and technology were to be established to succeed the electromobility pilot regions (pp. 55-57). Only a few days after the report appeared, the federal government itself went public with its own program, in which it basically adopted the NPE's strategic recommendations (German Federal Government, 2011). Simultaneously, the government assured it would provide $€ 1$ billion for R\&D activities in the upcoming years until late 2013. By contrast, it temporarily excluded direct market incentives, even though the NPE strongly recommended monetary incentives to achieve the ambitious and controversial goal of selling 1 million electric vehicles in Germany by 2020.

In October 2011 the government announced the funding program called Electromobility Showcases, which addressed primarily the regional level. In early 2012, at the end of the period we studied, the regions of Berlin/Brandenburg, BadenWuerttemberg, Lower Saxony, and Bavaria/Saxony were selected as the four showcases for Germany. Within a 3-year period the government was to provide a total of $€ 180$ million for the projects involved. Given the results of the NPE process-characterized by field-configuring or field-reconfiguring events-and the subsequent government program, it is presumably appropriate to note that the basic contours of 
a "national innovation system" (Nelson, 1993) for electromobility were developed in this 1-year period.

An important part of the state initiative in the Stuttgart region, besides the promotion of research infrastructure, was the creation of e-mobilBW, an entirely stateowned agency for electromobility and fuel-cell technology. The inaugural meeting of this entity took place in spring 2010. We think of this event as the second FCE in the region. Reflecting on the remarkable difference between this approach and former, uncoordinated practices, one interviewee claimed:

In Baden-Wuerttemberg we always have a bit of a problem. First, everyone works meticulously on his or her own, and it is sometimes hard if you say it has to be coordinated. But I think we are beyond that phase,...The awareness is there, we have to structure it, we have to somehow bundle it[.]...Therefore, I think we are well on the way right now. (Interview S002; September 2011)

The agency e-mobilBW is governed by a board of directors (politicians) and an advisory board (about 25 representatives of industry, science, and regional institutions). The main goals are to establish an efficient and effective network and cluster management (cf. Sydow, Schüßler \& Müller-Seitz, 2016: 103-159) and to serve as a center for consulting and knowledge transfer, aiming to provide for a useful topology of knowledge in the region. Furthermore, the agency is responsible for coordinating activities and creating synergies by also integrating small and medium-sized companies into the innovation process, and it is expected to support the creation of an adequate framework in the fields of infrastructure, education, and training (e-mobilBW, 2012). In 2011 the issue of electromobility was made a new core area in a state-wide automotive network named TecNet automotive bw, a decision that has reinforced the willingness of regional industry actors to engage in interorganizational coordination and projects. As one project executive stated: "Barriers that definitely existed have been lowered. ... The reservation we encounter among the suppliers is not as high as it was 2 years ago. Since we have been involved in these projects, the atmosphere has improved significantly" (Interview S005; September 2011).

Another FCE took place in spring 2011, when the proposal for the third round of the Leading-Edge Cluster Competition was presented publicly to regional stakeholders. Unlike the two abortive attempts in earlier years, this process was organized by e-mobilBW as a single point of contact. In January 2012 the application entitled Cluster Electromobility Southwest—Road to Global Market was ultimately accepted. Involving industries and federal financial support in equal measure, the program committed about $€ 80$ million to future $R \& D$ projects in the field of electromobility. At that time Daimler and Bosch, two of the leading automotive companies headquartered in the region, announced a joint venture in electric engines, with R\&D capacities located in the Stuttgart region and manufacturing capacities at a Bosch site in northern Germany. From then on it became increasingly evident that the installation of research infrastructure and the integration of small and mediumsized companies along the entire value chain were two of the highest priorities for industrializing the R\&D results in the region and not elsewhere (e-mobilBW, 2011). 
A representative of the automotive industry summarized the common goals and benefits of the regional platforming activities:

This means that the barriers...have to be highlighted and overcome by joint projects. At the same time, you have to involve medium-sized businesses, which are extremely strong in Baden-Wuerttemberg along this new path....And that is one of the central tasks of the forthcoming Cluster Electromobility Southwest. (Interview S003; September 2011)

In April 2012 the Stuttgart region became a showroom of applied science and technology, a "LivingLab BWe mobil," which is also being coordinated by e-mobilBW. More than 40 projects, encompassing an aggregate volume of some $€ 150$ million, have been set up. The programs are intended to reinforce each other, for $R \& D$ results can be tested immediately and practical insights taken into account in $\mathrm{R} \& \mathrm{D}$ activities.

In the Berlin region a second FCE also took place early in the formation phase, subsequent to the critical juncture, beginning in autumn 2010 with a high-level meeting of representatives of regional firms, institutions, and research organizations at the invitation of the city's Governing Mayor. It functioned as the starting point for creating the Berlin Agency for Electromobility (eMO), a regional coordinating institution, whose organizational and financial structure was negotiated and presented to selected regional stakeholders. Only a few days later, the establishment of eMO was publicly announced at a large venue to promote Berlin as a site for industry. The Action Plan for Electromobility, published a few months later, was one of the first results (eMO, 2011). At that time the NPE hinted at its expected recommendations to mount large-scale regional demonstration projects as an apt way to promote the development of electromobility. The action plan thus mainly supported the region's willingness to become a national showcase. The normative work done at that time was stressed by an interviewee: "The hope is eminent that if Berlin positions itself within this thematic field, it will get the chance to secure a slice of the new industrial value creation" (Interview B009; August 2011).

The third FCE occurred in summer 2011. Before the application process for the national showcase program, eMO organized a closed multistakeholder workshop with about 60 selected guests. As stated in the internal letter of invitation, the workshop was "to set the corresponding course" for the application. It did so by having the participants slip into the role of other stakeholders in order to become aware of further relevant perspectives and interests. Overall, this 2-day workshop marked the origin of the region's draft application. In the words of one participant,

Slowly but surely, core areas are being reinforced: Where do we want to go? What could the added value be in comparison to Bavaria or Baden-Wuerttemberg? What is our unique selling point? Now this process is being moderated by the agency, and the workshop was an important milestone. (Interview B007; August 2011)

The Berlin region was chosen as an international showcase in April 2012. About 35 key projects, accounting for a total volume of approximately $€ 165$ million (eMO, 2012) were set up. It is now commonly agreed that the upcoming projects of applied science and technology will serve as catalysts to attract R\&D capacities. This first step may be the basis for future value creation in the long run. This new perception 
may be seen as a major result of the platforming activities coordinated by eMO, for it signifies a fundamental shift away from wishful thinking to concrete and viable regional development activities compatible with the region's initial resources, competencies, and knowledge bases. "Getting from mere application to value creation in Berlin-that is the core strategy" (Interview B011; July 2011).

In summary, coordinating agencies were created in the Stuttgart and Berlin regions in 2010 and were implemented as platform organizers to facilitate a decidedly interorganizational exchange among proliferating, divergent interests and to foster and accelerate learning processes. Followed by other FCEs, these pooled knowledge bases provided by eMO and e-mobilBW thenceforth became the central "locale" (Giddens, 1984, p. xxv) for regional coordinating activities. Within these regional platforms central actor constellations stabilized in the field; interaction increased between the various stakeholders from industry, government, and science; and these actors became generally aware that they were involved in a common project. The field has become structured nationally as well as regionally (DiMaggio \& Powell, 1983). The incipient coordinating mechanism that connects the nexus of place-specific practices with the rules and resources in the field was arguably the salient result of this early stage of platforming policies in the two regions. Above all, clarification and stabilization of future priorities and project tasks was the main legacy of these regional platforming strategies by the time this phase ended in early 2012. Bearing in mind the interplay of the national and the regional scale, one interviewee with an academic background from the Stuttgart region concluded: "We are beginning to discern the line of march of the regional actors-who are coordinating themselves, of course. This gives them all a measure of certainty. And with this national framework, now this is reinforced even a bit further" (Interview S008; October 2011). However, these positive effects of platforming were not all that was highlighted. One interviewee with the Berlin region in mind also expounded on the problems of potentially dark sides (e.g., premature rigidity) due to increased coordination in this early phase of path-forming activities:

At some points you make decisions, but I think you have to be smart enough to reconsider [them] once in a while and ask yourself if this is the right path to take. ... I think there is a bit of a danger in wanting to stop or adjust the course once a train has begun moving. (Interview B007; August 2011)

This quotation indicates how much reflexivity was involved in the platforming process; though not everywhere all the time. The upper part of Fig. 10.1 summarizes the development of the national context; the two bottom parts, the developments in the two regions under study-Stuttgart and Berlin-between 2008 and early 2012.

\section{Discussion: Platforming Toward Path-Forming?}

The development of urban mobility based on the automotive system in general and cars with a traditional powertrain technology in particular indisputably illustrates a path-dependent process that has locked-in certain regions, indeed even whole 

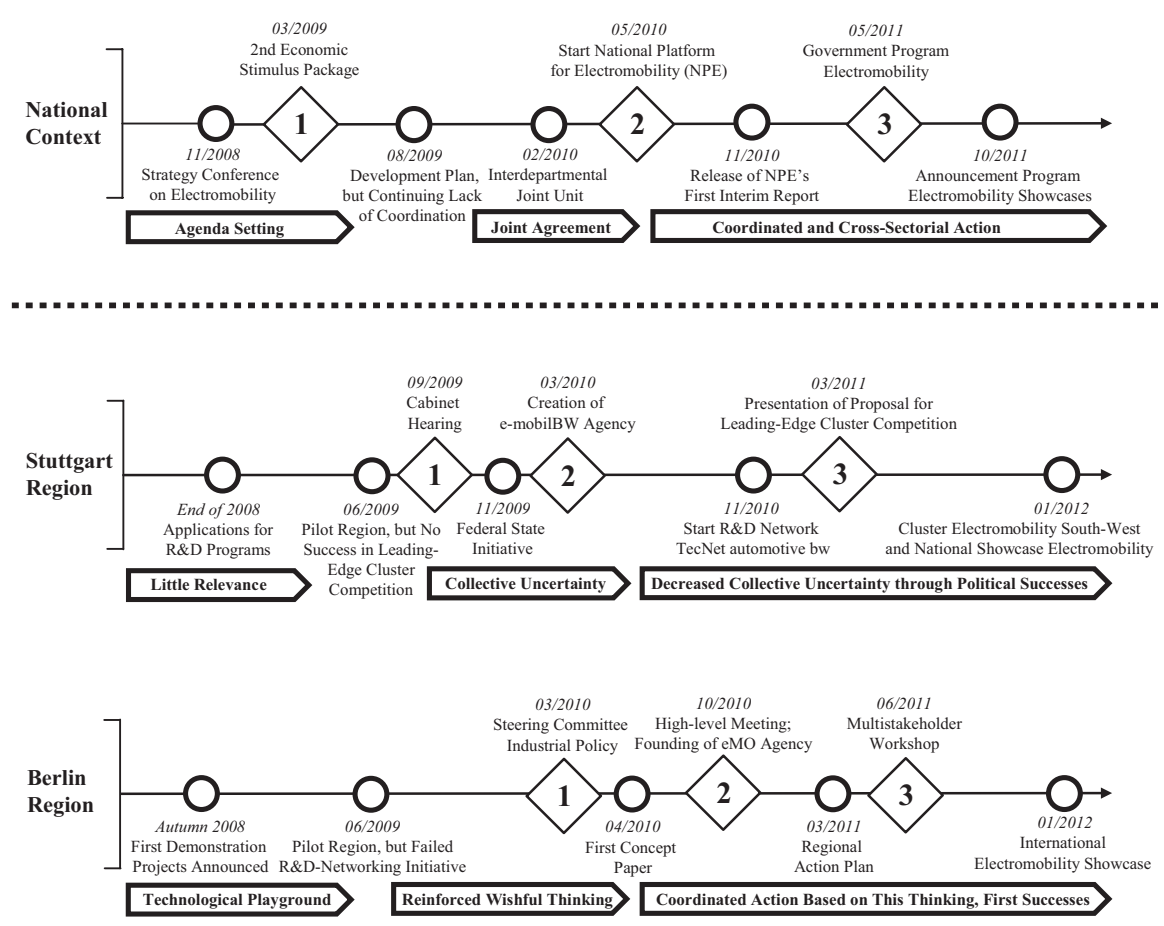

Fig. 10.1 Triggering events in the field of electromobility in the Stuttgart and Berlin regions (Design by authors)

societies, through positive feedback processes, which are fueled across several industries (Cowan \& Hultén, 1996; Dennis \& Urry, 2009, pp. 54-61; Kirsch, 2000). Given the interlocking technological, economic, and societal complexity of the automotive system, which is deeply ingrained in both the supply and demand side of modern societies with their organizations and institutions, platforming is unlikely to compete seriously with the present path either nationally or regionally. This inability to "unlock regional economies" (Hassink, 2005) particularly characterizes localities such as the Stuttgart region, with its organizations and institutions whose economic future is closely aligned with the automotive system. They depend on the present technology. But, as we have shown, it also distinguishes Berlin and similar regions that depend significantly less on the present powertrain technology.

Nonetheless, platforming is more than just an experimentation with possible future worlds, and as such it is more than only unsettling to actors treading the established and often strategically extended path (Sydow, Windeler, Schubert, \& Möllering, 2012). Instead, platforming helps open a window, on the supply side at least, by integrating a related variety of actor groups with divergent interests and complementary resources to foster cross-sectorial coordination and learning aimed at cross-fertilization. It can rather strongly stimulate construction of a complementary institutional infrastructure around which an alternative national or regional 
knowledge path may finally form. The more reflective, emphatic, and resourceful the platforming initiative is, the more likely this path-forming will be. To achieve these results, platforming requires certain conditions. It must be efficiently and effectively administered. It must be supported by diligently arranged national and regional FCEs and significant resource endowment (e.g., Germany's second economic stimulus package). It must be accompanied by successes (e.g., the creation of new organizations, the launching of R\&D projects, and the provision of early infrastructure for electromobility). Platforming also needs a suitable degree of related variety that combines, for instance, a well-prepared top-down approach with a bottom-up approach sensitive to regional competencies and political legacies. However, platforming will contribute to path-forming only if it is somewhat consistent with the expectations of the actors in the region and, in particular, their tolerance for change. Until then, platforming will not gain the momentum necessary even to complement the present knowledge path, let alone break or replace it (Grabher \& Stark, 1997).

It has become apparent that platforming activities do not come out of nowhere; they are based on preexisting regional competencies, resources, and knowledgebases (Asheim et al., 2011). Path-forming as a possible result of platforming can thus be fully understood only if one takes into account the preexisting technological, institutional, and organizational structures and paths and the constraining or enabling effects (Martin, 2010) they have on intersectorial and interorganizational coordination and learning activities in a regional setting. More precisely, platforming may be perceived as the locus of "the interaction of differences" (Cooke, 2012, p. 1419) and of purposeful and generative recombinations of existing activities or relations in a region. Besides the region's existing resource bases and other resources injected into the process of platforming, cognitive-normative orientations and context-sensitive framing activities seem to be highly important (Giddens, 1984).

In the two cases presented in this chapter, wishful thinking (the Berlin region) and collective uncertainty (the Stuttgart region) each had lasting impacts on the early formation of a new knowledge path despite quite effective attempts to reframe it. Take, for instance, the opposing motivations to implement the two regional platforms. The creation of the agency eMO in the Berlin region is largely explicable as an effort by regional stakeholders to moderate exaggerated expectations of industrial policy and transform them into a practicable approach. By contrast, the founding of the agency e-mobilBW in the Stuttgart region is interpretable mainly as the result of trying to convert exaggerated perception of threats into a realistic assessment, of seeking to balance protection of the existing industrial structure with encouragement of new technological developments. Whatever the cognitivenormative orientations and intentions behind attempts to promote or prevent the development of a new knowledge path, it seems crucial for the platforming strategy to explicitly address the diversity of stakeholder interests and orientations and allow for serious discourse about them. The two regions we have studied demonstrate that this diversity may, at best, be the source of creativity and novelty. At worst, it can block the collective creation of a proper and superior alternative perhaps needed for 
"effective restoration of a choice situation" (Sydow et al., 2009, p. 702) across organizational and industrial boundaries alike.

Compared to early experience with platforming in other countries (see Lazzeretti et al., 2010, pp. 31-34 for a review), the German encounter with electromobility seems significantly more burdened with issues of technological, institutional, and organizational path dependence. It also has-at least potentially-much greater socioeconomic scope and relevance. The two metropolitan electromobility regions we have investigated, Stuttgart and Berlin, are economically essential, though for different reasons. At the same time, the technological and institutional breakthrough needed there is more challenging than in others regions, not least because the Stuttgart and Berlin regional platforms established in the shadow of the NPE are, unsurprisingly, more diverse in their actors, activities, resources, and relations. The coordinative challenges facing the regional actors before the desired crossfertilization is likely to materialize are correspondingly difficult. Despite successful steps toward both the preformation and formation phases in the development of the new knowledge path, it is much too early to say whether a new path really will form and to question the existence of the old.

\section{Conclusions and Directions}

Starting necessarily from a focal region's existing knowledge base, platforming is commonly understood as a more combinative than cumulative and more generative than reproductive strategy that uses the related variety of agents, activities, resources, and relations to develop locally adapted solutions designed to avoid premature rigidity. In this regard platforming may complement traditional cluster policies rather than constitute a postcluster policy on its own. As long as cluster approaches do not incorporate additional ideas about related variety, platforming may serve as an effective antivenom to present cluster policies that reflect too little concern with the benefits of having diversity and the impact of rigidity that is too early.

But can a platforming strategy actually be used to break an established knowledge path such as the one related to the traditional powertrain technology driven by the internal combustion engine and embedded in a well-adapted organizational and institutional infrastructure that is itself characterized by path dependencies? To answer this question we examined the recent electromobility initiative in Germany, launched in response to global warming caused by high carbon emissions, and boosted in the aftermath of the global financial crisis in 2008. The case of the National Platform for Electromobility, which was introduced by the German government in 2010 and analyzed at the national level and in terms of two very different metropolitan regions, provided an excellent opportunity to inquire into the potential of platforming to unlock path dependencies.

We focused on the early stages of knowledge-path formation, drawing on theoretical insights into path dependence, path-breaking, platforming, and the role of FCEs in this strategy. We also used detailed data from two embedded and starkly 
contrasting cases (Yin, 2009) constituted by the Stuttgart and Berlin regions. It is there that the importance of agenda-setting at the federal level featured as prominently as the eventual creation and work of the NPE. Together, these national FCEs triggered-from the top down - a feasible process of regional path-formation flanked by similar regional events. In the years to come such events in the Stuttgart and Berlin metropolitan regions may acquire the critical mass and momentum necessary for new electromobility clusters to emerge. But if this process proves successful at all, it may well have a rather long way to go, and the results in the one region are likely to differ from those in the other, not least because of abundant path dependencies.

The Stuttgart region's inherited conditions, knowledge bases, and competencies on which subsequent complementary activities had to build were as different from those of the Berlin region as were the perceptions of the important regional actors (the collective uncertainty in the former area and the wishful thinking in the latter). Nevertheless, the actors in both regions were quite successful with their reframing activities and pushed to create new regional institutions, such as a formal coordination agency, harmonized local regulations, and stable practices of interorganizational and intersectorial coordination. These institutions seem to have functioned as a precondition for embedding the issue of electromobility rather securely in future regional development strategies. In the formation phase of the new knowledge path, which has only just begun, political successes have helped overcome at least some of the collective uncertainty experienced in Stuttgart and to make initial reality out of at least some of the wishful thinking that characterized the Berlin region. It is still unclear whether economic successes will follow the political achievements, although platform policies were increasingly carefully coordinated between the federal and regional levels. Even less clear is whether new clusters will arise from these activities in the distant future. The observed platforming activities, pushed forward by political initiatives, may be thought of as an important prerequisite of the effort to advance development toward BEVs, but these path-breaking attempts cannot be evaluated yet.

From our analysis we conclude that platforming opens new windows of opportunities but may be less likely to trigger the breaking of a national and regional knowledge path than some of its protagonists may expect (e.g., Cooke, 2007, p. 192; Harmaakorpi, 2006, p. 1090). Instead, platforming for path-breaking may culminate only in path-forming activities with a contingent outcome. This general insight awaits empirical testing in other settings and with research designs and methods more longitudinal than those feasible in the case studies we conducted. It would be useful to compare Germany's institutional specifics, which support collaboration between organizations in general and between firms and the government in particular, with those of other capitalist countries (Hall \& Soskice, 2001). Most importantly however, our research on the Stuttgart and Berlin metropolitan regions would have to be extended by several years - until the effects of platforming as path-forming became more visible. The platforming and path-forming processes need analysis even finer-grained than that which was possible in the present study, at least for selected episodes of stability and change. Additional ethnographic techniques 
would be useful for inquiry into such episodes. That kind of relatively long-term, detailed work would obviously contradict demands to widen the research to other regions and to extend the present study to fields other than electromobility and to nations other than Germany in order to improve the generalizability of our findings.

Despite these clear limitations of our study, we are confident that we have made at least three contributions. First, in terms of research on technological, institutional, and organizational path dependence (David, 1985, 2001; Mahoney, 2000; Manning \& Sydow, 2011; North, 1990; Pierson, 2000; Schreyögg, Sydow, \& Holtmann, 2011; Sydow et al., 2009, 2010), we have introduced the idea of platforming as a possible instrument for at least shaping, if not breaking, an existing path. Second, in continuing the emphasis that regional knowledge creation and exploitation receives in economic geography (and regional studies generally), we have, in more theoretical terms, also added to the knowledge-based theorizing of regional economic development that reflects the topology as much as the topography of knowledge (Bathelt et al., 2004; Cooke, 2001; Glückler, 2007, 2013; Malmberg \& Maskell, 2002). More precisely, our contribution lies in the exploration of platforming and of the concomitant role that field-configuring events have for creating new knowledge that both relates to and diverges from the present knowledge base in a region. Third, our study, particularly its focus on path dependence and possible path-breaking through platforming and attendant field-configuring events, contributes generally to the popular evolutionary and institutional theorizing about regional development processes (see Boschma \& Martin, 2010). That thinking seems increasingly sensitive to the importance of individual and organizational agency on the one hand and historical imprints and self-reinforcing, agency-delimiting processes on the other (Henning et al., 2013; Li et al., 2012; Martin \& Sunley, 2006; Tödtling \& Trippl, 2013). In this sense, we have drawn on the discussion in economic geography about the conceptual relation that platforming and related variety have with the enhancement of regional economic development processes. According to Boschma and Frenken (2011a), neither regional specialization (e.g., cluster policies) nor diversification (e.g., unrelated variety) is constructive in and of itself. Rather, related activities and shared competencies between diverse organizational actors in different industries or areas of expertise (related variety) seem to matter most for achieving knowledge spillovers and creating regional growth processes in a knowledge economy. However, platform policies designed to organize overlapping activities and to coordinate the interrelations of formerly unconnected sectors and interorganizational competencies may ultimately be insufficient on their own to help actors "leave well-trodden paths" (Sydow et al., 2010, p. 176) or to open a window for new path-forming activities. The extent to which they are up to that task remains to be seen. In the case of electromobility, the regional actors - from the demand as well as the supply side — need to stabilize and further institutionalize the preparatory platforming activities constantly. Only then may platforming finally acquire a self-reinforcing dynamic - the main shaper of a regional knowledge path. Despite this promising conceptual perspective, the current 
development in the field of electromobility still calls for a certain degree of skepticism, even pessimism.

Acknowledgments An early draft of this paper was presented at the symposium entitled "Knowledge \& Space-Topographies and Topologies of Knowledge" at the Villa Studio Bosch in Heidelberg, June 12-15, 2013. We thank Johannes Glückler for hosting this stimulating workshop and all the participants for their constructive comments. In addition, we are grateful to Udo Staber, Phil Cooke, and Elke Schüßler for insightful recommendations on how to improve the manuscript.

\section{References}

Arthur, W. B. (1994). Increasing returns and path dependency in the economy. Ann Arbor: University of Michigan Press.

Asheim, B., Boschma, R. A., \& Cooke, P. (2011). Constructing regional advantage: Platform policies based on related variety and differentiated knowledge bases. Regional Studies, 45, 893904. doi:10.1080/00343404.2010.543126

Bathelt, H. (2005). Geographies of production: Growth regimes in spatial perspective (II) Knowledge creation and growth in clusters. Progress in Human Geography, 29, 204-216. doi: $10.1191 / 0309132505 \mathrm{ph} 539 \mathrm{pr}$

Bathelt, H., \& Boggs, J. (2003). Toward a reconceptualization of regional development paths: Is Leipzig's media cluster a continuation of or a rupture with the past? Economic Geography, 79, 265-293. doi:10.1111/j.1944-8287.2003.tb00212.x

Bathelt, H., Malmberg, A., \& Maskell, P. (2004). Clusters and knowledge: Local buzz, global pipelines and the process of knowledge creation. Progress in Human Geography, 28, 31-56. doi:10.1191/0309132504ph469oa

Boschma, R. A., \& Fornahl, D. (2011). Cluster evolution and a roadmap for future research. Regional Studies, 45, 1295-1298. doi:10.1080/00343404.2011.633253

Boschma, R. A., \& Frenken, K. (2011a). Technological relatedness and regional branching. In H. Bathelt, M. Feldman, \& D. F. Kogler (Eds.), Beyond territory: Dynamic geographies of knowledge creation, diffusion, and innovation (pp. 64-81). Regions and Cities, Vol. 47. London, UK: Routledge.

Boschma, R. A., \& Frenken, K. (2011b). Technological relatedness, related variety and economic geography. In P. Cooke, B. Asheim, R. A. Boschma, R. Martin, D. Schwartz, \& F. Tödtling (Eds.), Handbook of regional innovation and growth (pp. 187-197). Cheltenham, UK: Edward Elgar.

Boschma, R. A., \& Martin, R. (Eds.). (2010). The handbook of evolutionary economic geography. Cheltenham, UK: Edward Elgar.

Collier, R. B., \& Collier, D. (1991). Shaping the political arena: Critical junctures, the labor movement, and regime dynamics in Latin America. Princeton: University Press.

Cooke, P. (2001). Regional innovation systems, clusters and the knowledge economy. Industrial and Corporate Change, 10, 945-974. doi:10.1093/icc/10.4.945

Cooke, P. (2007). To construct regional advantage from innovation systems first build policy platforms. European Planning Studies, 15, 179-194. doi:10.1080/09654310601078671

Cooke, P. (2011). Transversality and regional innovation platforms. In P. Cooke, B. Asheim, R. A. Boschma, R. Martin, D. Schwartz, \& F. Tödtling (Eds.), Handbook of regional innovation and growth (pp. 303-314). Cheltenham, UK: Edward Elgar. 
Cooke, P. (2012). From clusters to platform policies in regional development. European Planning Studies, 20, 1415-1424. doi:10.1080/09654313.2012.680741

Cooke, P., \& De Laurentis, C. (2010). Platforms of innovation: Some examples. In P. Cooke, C. De Laurentis, S. MacNeill, \& C. Collinge (Eds.), Platforms of innovation: Dynamics of new industrial knowledge flows (pp. 271-310). Cheltenham, UK: Edward Elgar.

Coombs, R., \& Hull, R. (1998). 'Knowledge management practices' and path-dependency in innovation. Research Policy, 27, 237-253. doi:10.1016/S0048-7333(98)00036-5

Cowan, R., \& Hultén, S. (1996). Escaping lock-in: The case of the electric vehicle. Technological Forecasting and Social Change, 53, 61-79. doi:10.1016/0040-1625(96)00059-5

David, P. (1985). Clio and the economics of QWERTY. American Economic Review, 75, 332-337.

David, P. (2001). Path dependence, its critics and the quest for 'historical economics'. In P. Garrouste \& S. Ioannides (Eds.), Evolution and path dependence in economic ideas: Past and present (pp. 15-40). Cheltenham, UK: Edward Elgar.

Dennis, K., \& Urry, J. (2009). After the car. Cambridge, UK: Polity Press.

DiMaggio, P. J., \& Powell, W. W. (1983). The iron cage revisited: Institutional isomorphism and collective rationality in organizational fields. American Sociological Review, 48, 147-160.

Eisenhardt, K. M. (1989). Building theories from case study research. Academy of Management Review, 14, 532-550. doi:10.5465/AMR.1989.4308385

eMO (Ed.). (2011). Action plan for electromobility Berlin 2020. Retrieved May 22, 2015, from https://www.berlin-partner.de/fileadmin/user_upload/01_chefredaktion/02_pdf/publikationen/ eMO\%20Aktionsprogramm\%20\%28english\%29.pdf

eMO (Ed.). (2012). Berlin-Brandenburg international showcase for electromobility: Application summary. Retrieved May 22, 2015, from http://www.emo-berlin.de/fileadmin/user_upload/ Downloads/English/120904_eMO_Bewerbung_EN.pdf

e-mobilBW (Ed.). (2011). Structure study BWe Mobile 2011: Baden-Wuerttemberg on the way to electromobility. Retrieved March 3, 2013, from http://www.e-mobilbw.de/en/publications. html?file=files/e-mobil/content/DE/Publikationen/PDF/e_mobil_structure_study_en.pdf

e-mobilBW (Ed.). (2012). The e-mobilBW GmbH: Start now in the future of Electric Mobility. Retrieved March 3, 2013, from http://www.e-mobilbw.de/en/publications.html?file=files/ e-mobil/content/DE/Publikationen/PDF/0356_Broschuere_englisch_RZ_5-web_final.pdf

Expert Commission on Research and Innovation (Ed.). (2010). Report on research, innovation and technological performance in Germany 2010. Retrieved May 4, 2014 from http://www.e-fi.de/ fileadmin/Gutachten/2010_engl.pdf

Flaig, I. (2009, September 30). Land bei Elektroauto im Hintertreffen: Wirtschaft drängt Oettinger [Federal state of Baden-Wuerttemberg falls behind on electric cars: Industry pressures the state's minister president]. Stuttgarter Nachrichten. Retrieved from http://www.stuttgarternachrichten.de/inhalt.wirtschaft-draengt-oettinger-land-bei-elektroauto-im-hintertreffen. f2289c33-3ac8-40a8-9eec-fd2c713e-4b13.html

Frenken, K., van Oort, F., \& Verburg, T. (2007). Related variety, unrelated variety and regional economic growth. Regional Studies, 41, 685-697. doi:10.1080/00343400601120296

Fuchs, G. (2010). Path dependence in regional development: What future for Baden-Württemberg? In G. Schreyögg \& J. Sydow (Eds.), The hidden dynamics of path dependence: Institutions and organizations (pp. 178-194). London, UK: Palgrave Macmillan.

Fuchs, G., \& Wassermann, S. (2005). Path dependency in Baden-Württemberg: Lock-in or breakthrough? In G. Fuchs \& P. Shapira (Eds.), Rethinking regional innovation and change: Path dependency or regional breakthrough? (pp. 223-248). New York: Springer.

German Federal Government (Ed.). (2007). Eckpunkte für ein integriertes Energie- und Klimaprogramm [Key elements of an integrated energy and climate program]. Retrieved May 4, 2014, from http://www.bmwi.de/BMWi/Redaktion/PDF/E/eckpunkt-fuer-ein-integriertesenergie-und-klimaprogramm.pdf 
German Federal Government (Ed.). (2009). National Electromobility Development Plan. Retrieved May 4, 2014, from http://www.bmwi.de/English/Redaktion/Pdf/national-electromobilitydevelopment-plan.pdf

German Federal Government (Ed.). (2010). Establishment of the National Platform for Electromobility on May 3, 2010: Joint declaration by the Federal Government and German industry. Retrieved May 4, 2014, from http://www.bmwi.de/EN/Press/pressreleases, did $=346562 . \mathrm{html}$

German Federal Government (Ed.). (2011). Regierungsprogramm Elektromobilität [Government electromobility program]. Retrieved May 4, 2014, from http://www.bmbf.de/pubRD/programm_elektromobilitaet.pdf

Giddens, A. (1984). The constitution of society: Outline of the theory of structuration. Cambridge, UK: Polity Press.

Glückler, J. (2007). Economic geography and the evolution of networks. Journal of Economic Geography, 7, 619-634. doi:10.1093/jeg/lbm023

Glückler, J. (2013). Knowledge, networks and space: Connectivity and the problem of non-interactive learning. Regional Studies, 47, 880-894. doi:10.1080/00343404.2013.779659

Grabher, G. (1993). The weakness of strong ties: The lock-in of regional development in the Ruhr Area. In G. Grabher (Ed.), The embedded firm: On the socioeconomics of industrial networks (pp. 255-277). London, UK: Routledge.

Grabher, G., \& Stark, D. (1997). Organizing diversity: Evolutionary theory, network analysis and postsocialism. Regional Studies, 31, 533-544. doi:10.1080/00343409750132315

Hall, P. A., \& Soskice, D. (Eds.). (2001). Varieties of capitalism: The institutional foundations of comparative advantage. Oxford: University Press.

Harmaakorpi, V. (2006). Regional Development Platform Method (RDPM) as a tool for regional innovation policy. European Planning Studies, 14, 1085-1104. doi:10.1080/096543106 00852399

Harmaakorpi, V., Tura, T., \& Melkas, H. (2011). Regional innovation platforms. In P. Cooke, B. Asheim, R. A. Boschma, R. Martin, D. Schwartz, \& F. Tödtling (Eds.), Handbook of regional innovation and growth (pp. 556-572). Cheltenham, UK: Edward Elgar.

Hassink, R. (2005). How to unlock regional economies from path dependency? From learning region to learning cluster. European Planning Studies, 13, 521-535. doi:10.1080/09654310500107134

Hassink, R. (2010). Locked in decline? On the role of regional lock-ins in old industrial areas. In R. A. Boschma \& R. Martin (Eds.), The handbook of evolutionary economic geography (pp. 450-468). Cheltenham, UK: Edward Elgar.

Henning, M., Stam, E., \& Wenting, R. (2013). Path dependence research in regional economic development: Cacophony or knowledge accumulation? Regional Studies, 47, 1348-1362. doi: $10.1080 / 00343404.2012 .750422$

Ibert, O. (2007). Towards a geography of knowledge creation: The ambivalences between 'knowledge as an object' and 'knowing in practice'. Regional Studies, 41, 103-114. doi: $10.1080 / 00343400601120346$

Kaiser, W. (2007). Regionales Cluster oder globaler Knoten? Automobiltechnik im Raum Stuttgart [Regional cluster or global knot? Automotive engineering in the Stuttgart region]. In $\mathrm{H}$. Berghoff \& J. Sydow (Eds.), Unternehmerische Netzwerke: Eine historische Organisationsform mit Zukunft? (pp. 175-195). Stuttgart, Germany: Kohlhammer.

Kay, N. M. (2013). Rerun the tape of history and QWERTY always wins. Research Policy, 42, 1175-1185. doi:10.1016/j.respol.2013.03.007

Kirsch, D. A. (2000). The electric vehicle and the burden of history. New Brunswick: Rutgers University Press. 
Lagerholm, M., \& Malmberg, A. (2009). Path dependence in economic geography. In L. Magnusson \& J. Ottosson (Eds.), The evolution of path dependence (pp. 87-107). Cheltenham, UK: Edward Elgar.

Lampel, J., \& Meyer, A. D. (2008). Field-configuring events as structuring mechanisms: How conferences, ceremonies, and trade shows constitute new technologies, industries, and markets. Journal of Management Studies, 45, 1025-1035. doi:10.1111/j.1467-6486.2008.00787.x

Lange, B., Kalandides, A., Stöber, B., \& Mieg, H. A. (2008). Berlin's creative industries: Governing creativity? Industry \& Innovation, 15, 531-548. doi:10.1080/13662710802373981

Langley, A. (1999). Strategies for theorizing from process data. Academy of Management Review, 24, 691-710. doi:10.5465/AMR.1999.2553248

Lazzeretti, L., Capone, F., \& Cinti, T. (2010). The regional development platform and 'related variety': Some evidence from art and food in Tuscany. European Planning Studies, 18, 27-45. doi:10.1080/09654310903343518

Lazzeretti, L., Sedita, S. R., \& Caloffi, A. (2014). Founders and disseminators of cluster research. Journal of Economic Geography, 14, 21-43. doi:10.1093/jeg/lbs053

Li, P.-F., Bathelt, H., \& Wang, J. (2012). Network dynamics and cluster evolution: Changing trajectories of the aluminium extrusion industry in Dali, China. Journal of Economic Geography, 12, 127-155. doi:10.1093/jeg/lbr024

Mahoney, J. (2000). Path dependence in historical sociology. Theory and Society, 29, 507-548. doi:10.1023/A:3A1007113830879

Malmberg, A., \& Maskell, P. (2002). The elusive concept of localization economies: Towards a knowledge-based theory of spatial clustering. Environment and Planning A, 34, 429-449. doi:10.1068/a3457

Manning, S., \& Sydow, J. (2011). Projects, paths, and practices: Sustaining and leveraging projectbased relationships. Industrial and Corporate Change, 20, 1369-1402. doi:10.1093/icc/dtr009

Martin, R. (2010). Roepke lecture in economic geography - Rethinking regional path dependence: Beyond lock-in to evolution. Economic Geography, 86, 1-27. doi:10.1111/j.1944-8287.2009. 01056.x

Martin, R., \& Sunley, P. (2003). Deconstructing clusters: Chaotic concept or policy panacea? Journal of Economic Geography, 3, 5-35. doi:10.1093/jeg/3.1.5

Martin, R., \& Sunley, P. (2006). Path dependence and regional economic evolution. Journal of Economic Geography, 6, 395-437. doi:10.1093/jeg/lb1012

Maskell, P. (2001). Towards a knowledge-based theory of the geographical cluster. Industrial and Corporate Change, 10, 921-943. doi:10.1093/icc/10.4.921

Maskell, P., Bathelt, H., \& Malmberg, A. (2006). Building global knowledge pipelines: The role of temporary clusters. European Planning Studies, 14, 997-1013. doi:10.1080/09654310600 852332

Meyer, A. D., Gaba, V., \& Colwell, K. (2005). Organizing far from equilibrium: Nonlinear change in organizational fields. Organization Science, 16, 456-473. doi:10.1287/orsc. 1050.0162

Morgan, K. (1997). The learning region: Institutions, innovation and regional renewal. Regional Studies, 31, 491-503. doi:10.1080/00343409750132289

National Academy of Science and Engineering (Ed.). (2010). Wie Deutschland zum Leitanbieter für Elektromobilität werden kann [How Germany can become the lead supplier of electromobility]. Berlin: Springer.

National Platform for Electromobility (Ed.). (2010). Interim report. Retrieved May 4, 2014, from http://www.bmwi.de/English/Redaktion/Pdf/electro-mobility-report

National Platform for Electromobility (Ed.). (2011). Second report. Retrieved May 4, 2014, from http://www.bmwi.de/English/Redaktion/Pdf/second-report-of-the-national-platform-for-electromobility.pdf 
Nelson, R. R. (1993). National innovation systems: A comparative analysis. Oxford: University Press.

Nooteboom, B. (1997). Path dependence of knowledge: Implications for the theory of the firm. In L. Magnusson \& J. Ottosson (Eds.), Evolutionary economics and path dependence (pp. 57-78). Cheltenham, UK: Edward Elgar.

North, D. C. (1990). Institutions, institutional change and economic performance. Cambridge, UK: Cambridge University Press.

Pettigrew, A. M. (1990). Longitudinal field research on change: Theory and practice. Organization Science, 1, 267-292. doi:10.1287/orsc.1.3.267

Pierson, P. (2000). Increasing returns, path dependence, and the study of politics. American Political Science Review, 94, 251-267.

Porter, M. E. (2000). Locations, clusters, and company strategy. In G. L. Clark, M. S. Gertler, \& M. P. Feldman (Eds.), The Oxford handbook of economic geography (pp. 253-274). Oxford: University Press.

Schreyögg, G., Sydow, J., \& Holtmann, P. (2011). How history matters in organizations-The case of path dependence. Management \& Organization History, 6, 81-100. doi:10.1177/17449359 10387030

Schüßler, E., Rüling, C. C., \& Wittneben, B. B. F. (2014). On melting summits: The limitations of field-configuring events as catalysts of change in transnational climate policy. Academy of Management Journal, 57, 140-171. doi:10.5465/amj.2011.0812

State Ministry of Baden-Wuerttemberg (Ed.). (2009, November 20). Pressemitteilung 4. Landeskonferenz Automobilwirtschaft Baden-Württemberg [Press release, 4th conference of the automotive industry in Baden-Wuerttemberg]. Retrieved from http://www.baden-wuerttemberg.de/de/service/presse/pressemitteilung/pid/4-landeskonferenz-automobilwirtschaft-i n-baden-wuerttemberg/

Strambach, S., \& Klement, B. (2013). Exploring plasticity in the development path of the automotive industry in Baden-Württemberg: The role of combinatorial knowledge dynamics. Zeitschrift für Wirtschaftsgeographie, 57, 67-82.

Sydow, J., Lerch, F., \& Staber, U. (2010). Planning for path dependence? The case of a network in the Berlin-Brandenburg optics cluster. Economic Geography, 86, 173-195. doi:10.1111/j.1944-8287.2010.01067.x

Sydow, J., Schreyögg, G., \& Koch, J. (2009). Organizational path dependence: Opening the black box. Academy of Management Review, 34, 689-709.

Sydow, J., Windeler, A., Schubert, C., \& Möllering, G. (2012). Organizing R\&D consortia for path creation and extension: The case of semiconductor manufacturing technologies. Organization Studies, 33, 907-936. doi:10.1177/0170840612448029

Sydow, J., Schüßler, E., \& Müller-Seitz, G. (2016). Managing inter-organizational relations. London: Palgrave Macmillan.

Thelen, K. (1999). Historical institutionalism in comparative politics. Annual Review of Political Science, 2, 369-404. doi:10.1146/annurev.polisci.2.1.369

Tödtling, F., \& Trippl, M. (2013). Transformation of regional innovation systems: From old legacies to new development paths. In P. Cooke (Ed.), Re-framing regional development: Evolution, innovation and transition (pp. 297-317). Regions and Cities: Vol. 62. London, UK: Routledge.

Uotila, T., Harmaakorpi, V., \& Hermans, R. (2012). Finnish mosaic of regional innovation system: Assessment of thematic regional innovation platforms based on related variety. European Planning Studies, 20, 1583-1602. doi:10.1080/09654313.2012.713331 
Wolfe, D. A. (2013). Regional resilience, cross-sectoral knowledge platforms and the prospects for growth in Canadian city regions. In P. Cooke (Ed.), Re-framing regional development: Evolution, innovation and transition (pp. 54-72). Regions and Cities: Vol. 62. London, UK: Routledge.

Wolfe, D. A., \& Gertler, M. S. (2006). Local antecedents and trigger events: Policy implications of path dependence for cluster formation. In P. Braunerhjelm \& M. P. Feldman (Eds.), Cluster genesis: Technology-based industrial development (pp. 243-263). Oxford: University Press.

Yin, R. K. (2009). Case study research: Design and methods (4th ed.). Applied Social Research Methods Series: Vol. 5. Thousand Oaks: Sage.

Open Access This chapter is distributed under the terms of the Creative Commons Attribution 4.0 International License (http://creativecommons.org/licenses/by/4.0/), which permits use, duplication, adaptation, distribution and reproduction in any medium or format, as long as you give appropriate credit to the original author(s) and the source, provide a link to the Creative Commons license and indicate if changes were made.

The images or other third party material in this chapter are included in the work's Creative Commons license, unless indicated otherwise in the credit line; if such material is not included in the work's Creative Commons license and the respective action is not permitted by statutory regulation, users will need to obtain permission from the license holder to duplicate, adapt or reproduce the material. 